\title{
Prospettiva Soldatesca: An Empirical Approach to the Representation of Military Architecture in the Early Modern Period
}

\author{
Miguel Ángel Alonso-Rodríguez · José Calvo-López
}

Published online: 22 November 2014

(C) Kim Williams Books, Turin 2014

\begin{abstract}
The paper deals with the history of military perspective, that is, cavalier perspective with a horizontal projection plane. After surveying briefly its remote origins in ancient and mediaeval transoblique or 'Egyptian' perspective, the authors explain how military perspective arose to fulfill the needs of military architecture representation, in particular the depiction of the new bastion systems that were introduced in the late fifteen and sixteenth centuries as an answer to the appearance of gunpowder and artillery. Next, the paper follows its gradual expansion into broader fields as a general technical drawing procedure, while remarking a puzzling fact: until the 19th, this technique was not conceived as a projection, in contrast to orthographic drawing and linear perspective. Nevertheless, its awkard 'legalisation' in the late nineteenth century paved the way for its adoption as the most significant graphic device of the architecture of the twentieth century.
\end{abstract}

Keywords Military architecture - Fortresses - Bastions · Architectural representation - Military perspective $\cdot$ Cavalier perspective $\cdot$ Francesco di Giorgio Martini · Baldassare Peruzzi - Giovanni Battista Zanchi · Robert Corneweyle · Buonaiuto Lorini · Hendrik Hondius · Jean Du Breuil · Auguste Choisy

\footnotetext{
M. Á. Alonso-Rodríguez

Escuela Superior de Arquitectura, Avda., Juan de Herrera, 4, 28040 Madrid, Spain e-mail: miguel.alonso@upm.es

J. Calvo-López ( $₫)$

Escuela de Arquitectura e Ingeniería de Edificación, Universidad Politécnica de Cartagena,

Paseo Alfonso XIII, 50, 30203 Cartagena, Spain

e-mail: jose.calvo@upct.es
} 


\section{Prelude: Transoblique perspective in Antiquity and the Middle Ages}

Reichlin (1979) and Scolari (1984, 2005) have stressed the role of axonometric drawing as the canonical representation method in the architecture of the Modern Movement. Most of the axonometrics of Le Corbusier and Alberto Sartoris are of a peculiar kind: cavalier perspectives with horizontal projection planes or, more precisely, parallel projections with a horizontal projection plane and the centre of projection located at infinity in an oblique direction to the projection plane. Such representation method arose in military architecture treatises of the fifteenth and sixteenth centuries, and was thus known as prospettiva soldatesca or military perspective (Maggi and Castriotto 1564; see also Càndito 2009), a term that stresses its simplicity and convenience, its empirical nature, and its lack of sophistication when compared with linear perspective: in a word, its rough-and-ready character.

Although the first true military perspectives appeared at the end of the fifteenth century, this representation technique has its roots in a number of Antique and Mediaeval drawing practices, in particular a technique that was revived in the twentieth century by John Hedjuk, sometimes dubbed 'transoblique perspective', or, improperly, 'Egyptian perspective'. At first glance such representations may seem arbitrary. However, they can be constructed by means of an oblique parallel or cylindrical projection, although such idea was probably quite far from the minds of its ancient and mediaeval practitioners. Suppose you want to draw a cube in transoblique perspective. You can lay a horizontal projection plane under the cube and use projectors that are parallel to the lateral faces of the cube, while forming $45^{\circ}$ with the projection plane (Fig. 1). In such a projection, the horizontal faces of the cube will
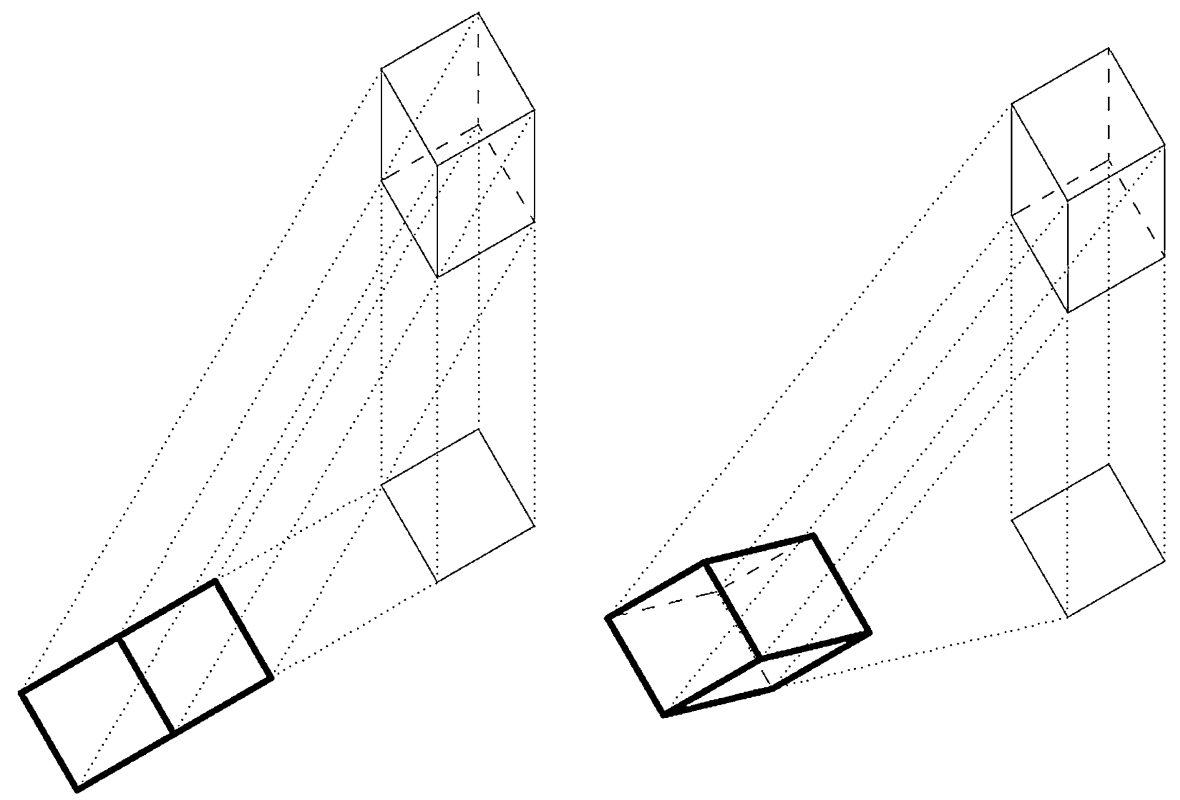

Fig. 1 Transoblique and military projections of a cube 
keep their shape. The vertical edges of the cube, their projectors and their projections will form an isosceles triangle; as a result, the vertical edges of the cube will keep their length. Since the horizontal edges of the cube also retain their length, the front face of the cube will also keep its shape. As for the lateral faces of the cube, they will be projected as line segments, since they are parallel to the projectors. This fact deprives transoblique perspective of three-dimensional character of axonometry; this is why Hedjuk's drawings are much harder to understand than ordinary axonometrics.

In any case, transoblique perspectives, although not so frequent as ordinary parallel perspectives, were used in antiquity, for example in a well-known Pompeian fresco depicting a quarrel between hooligans from Pompeii and Nocera resulting in the destruction of the amphitheatre of this city; even more frequent is another variation of this representational method, known as lateral perspective, which shows in true shape and form both elevations of a building or artefact, while reducing horizontal planes to lines, such as the fresco of a chariot in the tomb of Philippus of Macedonia in Vergina.

Both forms of representation, lateral and transoblique perspective, are usual in miniatures of the High Middle Ages, showing churches or Heavenly Jerusalem. Transoblique perspective appears in the well-known drawings of the radial chapels of Reims cathedral in the portfolio of Villard de Honnecourt (1225), which have been sometimes considered failed linear perspectives. Of course, taking into account our preceding explanation of the rationale of transoblique perspective, we should consider them as the result of a different method of representation, although nothing suggests that Villard had in mind the concept of projection.

Another late mediaeval drawing, not so well known as those of Villard, is particularly useful for our purposes. Hans Boblinger's drawing of the hospital at Eslingen, dating from 1503, depicts a side of the hospital church in transoblique perspective: buttress fronts are shown in true shape, while their sides are reduced to lines. By contrast, some buttresses at the choir of the church are depicted in a different way. Both the fronts and the sides of these buttresses undergo a deformation, while we can surmise that the horizontal upper part of the buttress keeps its true shape, just as in Le Corbusier's drawing of the villa in Garches, where the side elevations are subject to different degrees of deformation, while the roof is shown in true form (Fig. 2). This partial use of military perspective by Boblinger seems to have occurred by chance, as an unwanted result of the rotation of the choir buttresses.

The first examples of true, deliberate use of military perspective date from this period, and are found in the manuscripts of Francesco di Giorgio Martini. In order to analyse the relation with bird's eye perspective and the invention of the bastion, we shall deal in the next section with the oldest manuscripts by Martini, depicting for the most part high-rise castles in linear perspective, and only afterwards we shall analyse the later ones, including bastions and true military perspective.

\section{Francesco di Giorgio Martini: High-rise Castles in Codex Saluzziano and Codex Ashburnhamiano}

The oldest Renaissance treatises dealing with military architecture were written by Francesco di Giorgio Martini, an architect, sculptor, painter and military architect 


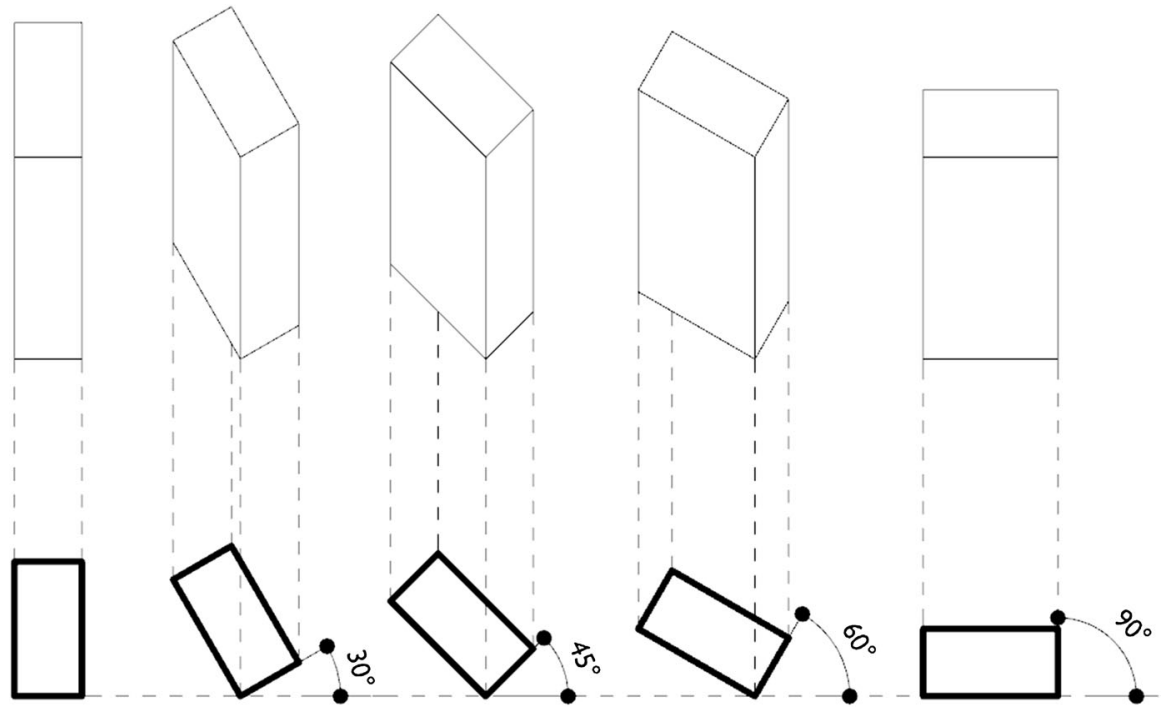

Fig. 2 Oblique axonometric drawing of a set of rotated boxes. Depending on their orientation, they appear to be depicted in transoblique or military perspective

born in Siena in 1439; he died probably in the same city in 1501. He undertook a large number of commissions in military architecture, first for the Dukes of Urbino, Federico di Montefeltro and his son Guidobaldo, and later on for the signoria of Siena and the Duke of Calabria. None of this prevented him from acting as an advisor for the construction of the tiburio (dome) of Milan cathedral, and the crossing at Pavia cathedral, as well as writing two unpublished treatises on architecture and civil and military engineering.

These treatises pose complex problems, in particular regarding their date. Four manuscripts and two sets of notes and drawings have been preserved. Codex Saluzziano 148 in the Royal Library in Torino (Martini 1480a) and the incomplete Codex Ashburnhamiano 361 in the Biblioteca Laurenziana in Florence (Martini 1480b) are essentially identical, being copies of a lost text dating from 1480 to 1485 , with the title Architettura, Ingegneria e Arte Militare. The other two manuscripts, Senese S. IV. 4 at the National Library in Siena (Martini 1490a) and the Codex Magliabecchiano II. 1. 141 in the National Library in Florence (Martini 1490b), are copies of a different treatise, Architettura civile e militare, but they are by no means identical. While the Siena manuscript includes few drawings, the Magliabecchiano is lavishly illustrated and includes a translation of Vitruvius that is lacking in the Senese one. Both seem to date from about 1490, if not later. Besides, there is a portfolio or Codicetto of annotated drawings in the Vatican Library and another group of drawings, without notes, in the British Library, known as Opusculum de architectura. All this explains why the first edition of a Martini treatise, published in Torino in 1841, was based on the Magliabecchiano (Maltese 1967).

Although quite a number of studies about Martini have been published, most of them deal with the text from a historical and chronological point of view, while the 
drawings themselves have not been the object of such thorough study. Besides, it is still not clear which manuscripts are from Martini's hand and their exact date. Only the drawings in the Vatican notebook are widely accepted as coming from Martini's hand. Most scholars date all manuscripts before the death of Martini (Reti 1963; Maltese 1967: xxvi); however, Alessandro Parronchi (1982) has posited that the Magliabecchiano and the Siena manuscript were derived from a manuscript on military architecture by Baldassare Peruzzi (1481-1536), a disciple of Martini, preserved in the Accademia delle Belle Arti in Florence. In any case, the surviving manuscripts by Martini should be considered as a complex corpus, the result of a number of successive re-elaborations by Martini and, maybe, by other authors.

For Maltese (1967: xxvii), when writing his treatises, Martini was seeking two goals:

The main aim, as Schlosser made clear in 1924, was to prepare a modern equivalent of the Vitruvian treatise. Another aim was to explain the advances in the fortification technique in the period, which underwent a fast evolution, taking into account the changes that were taking place in this historical context.

Although Martini includes in the Saluzziano and the Magliabecchiano such issues as weapons or water-elevating machines, the main part of his text deals with civil and military architecture. While he shows a strong Vitruvian influence in civil architecture, when dealing with fortification he puts forward a number of new defensive solutions. Moreover, the graphical devices used when dealing with the two kinds of architecture are different. For civil architecture, Martini relies mostly on plans, although in the Saluzziano he uses also elevations and perspective sections. When dealing with the representation of interior space in Italian Renaissance architectural drawings, Lotz (1977) analysed these representations, and in particular such drawings as the ones for the Pantheon (Fig. 3) or Santa Constanza: "The artist has placed the point of view higher than the floor, but lower than the main cornice, so that it is placed approximately at eye level. Thus, this perspective construction still follows the principles of Alberti ..." He was, of course, quoting the well-known passage in Alberti's 1435 De Pictura that advises the reader to place the point of view no higher from the base line than the height of the man to be represented, for in this way both the viewers and the objects in the painting will seem to be on the same plane (Alberti 2004: 54).

However, all this holds only for civil architecture. In contrast, when dealing with military architecture, he uses plans and bird's eye linear perspectives. For Benevolo (2003: 170) this combination of different representation techniques should be interpreted as a result of "one of the strongest requests of late-fifteenth-century culture, which demands for each notion different visual information, seeking to match scientific research with a systematic representation of the form of each object".

There is a good reason for this unusual placement of the point of view. In the case of military architecture, placing the station point at eye level, as suggested by Alberti, would result in a meaningless elevation of the walls of a castle. Instead, by raising the point of view, the draughtsman can furnish a detailed representation of 
Fig. 3 Francesco di Giorgio Martini (1480a). Perspective section of the Pantheon. Codex Saluzziano, fol. 80. Reproduced by concession of the Ministry of Cultural Assets and Activities and Tourism of Italy. Biblioteca Reale, Torino

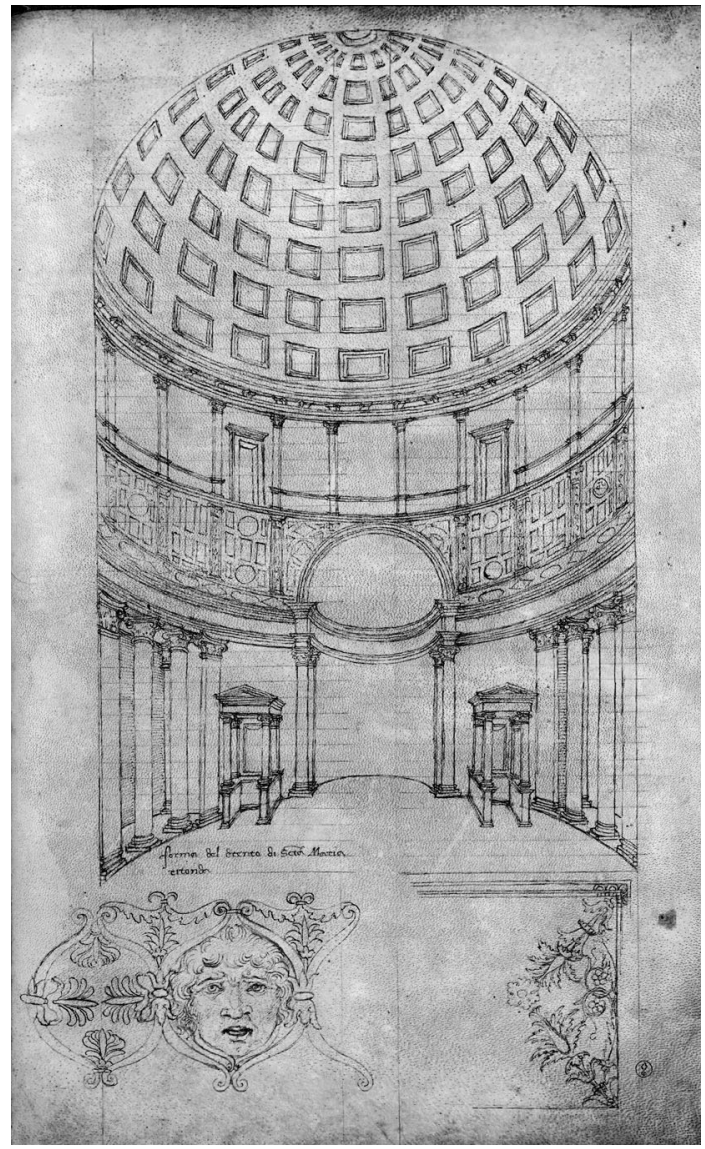

the ensemble of a fortress, including its interior layout. Further, the perspectives in the Codex Saluzziano are prepared in such a way that no element in the foreground disturbs the view of the background construction; the station point is carefully placed so that the highest towers stand at the sides of the drawing and do not hide other pieces in the fortification.

In any case, these drawings, placed on the sides of the sheets, and overlaid with text in some occasions, are not technically perfect: parallel lines do not converge generally at a vanishing point and in fact meet in the foreground in some drawings; in other cases, they are almost parallel. Such heterodoxy bears the marks of a graphical technique in its initial stages. Besides, most castles and fortresses in these manuscripts include interior constructions, usually a donjon or central tower, a strong last stand. In order to emphasize the three-dimensional appearance of such designs, the draughtsman uses shades in a number of faces with the same orientation, but not cast shadows; thus he manages to convey a strong feeling of volume, while showing the ensemble clearly.

In the later manuscripts we can find almost literal copies of these representations. For example, the fortresses in ff. 81 and $75 \mathrm{v}$ of the Magliabecchiano are taken from 
Fig. 4 Francesco di Giorgio Martini (1480a). Bird's eye perspective of a fortress. Codex Saluzziano, fol. 4 v. Reproduced by concession of the Ministry of Cultural Assets and Activities and Tourism of Italy. Biblioteca Reale, Torino

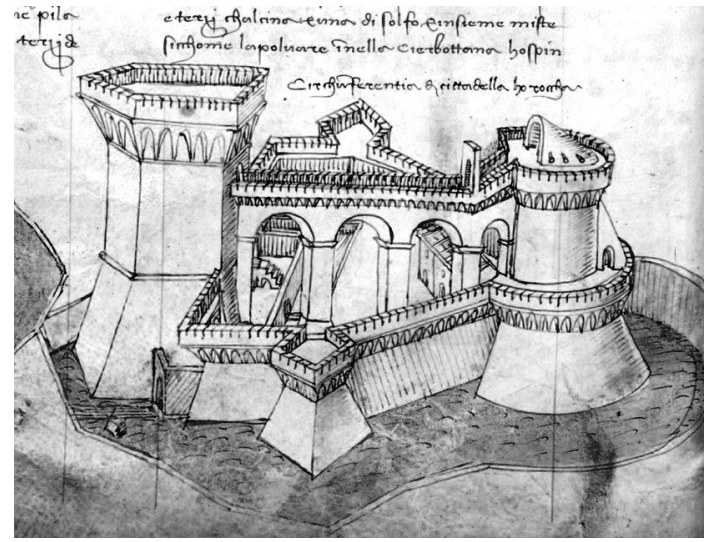

Fig. 5 Francesco di Giorgio Martini (1490b). Bird's eye perspective of a fortress. Codex Magliabecchiano, fol. 81.

Reproduced by permission of Biblioteca Nazionale Centrale, Firenze

ff. 4 and $4 \mathrm{v}$ in the Saluzziano (Figs. 4, 5). In the first of these drawings there is a castle with two towers, joined by a bridge; in the copy, some arches are suppressed, but the ensemble is essentially identical. The shades and the level of detail are quite similar, although in the Magliabecchiano the drawings use the whole sheet and not only the margins.

\section{Francesco di Giorgio Martini and/or Baldassare Peruzzi: the bastion systems in Codex Magliabecchiano, Codex Senese and the manuscript of the Accademia delle Belle Arti}

The Magliabecchiano also includes a number of original drawings of a new type of fortress, including bastions in the corners in order to protect the curtains and 
eliminating high towers; according to Julius von Schlosser (1924), such designs were Martini's own invention. These solutions, which are quite scarce in the Saluzziano and Ashburnhamiano manuscripts, arose as an answer to the increasing importance of gunpowder and guns in the fifteenth century. These innovations fostered sudden changes in defensive techniques and the conception of fortresses. In this period, the goals of defensive design include not only making enemy access as difficult as possible, but also providing for the defence of the fortress by means of guns and other firearms, while resisting the enemy's artillery. Brick takes the place of stone, while the high walls traditionally used to prevent the attack by means of siege towers are eschewed for low-profile curtains, in order to prevent the frontal impact of cannonballs. All this makes the shape of the perimeter of the fortress essential; thus, Martini adopts a novel drawing technique in order to show the outline of curtains and bastions as clearly as possible (Figs. 6, 7).

Arnau (1988: III-128) has stressed the use of axonometry in these drawings: "Either when the fortress is built on flat ground or when depicting a rocca built on a hill, Di Giorgio uses mainly axonometry for these drawings, and only occasionally linear perspective and plans, in particular for details". It is worthwhile to remark that the author of the Magliabecchiano drawings does not use the plan for these fortresses, even on those occasions where the plan would have furnished the easiest solution. In particular, one of the few examples of bastions in the Ashburnhamiano, the sawtooth design on fol. 5, drawn in plan, reappears in the Magliabecchiano, on fol. $61 \mathrm{v}$, in military perspective, that is, a kind of parallel projection that preserves the shape of figures laid out in horizontal planes (Figs. 8, 9).

Quite probably, the inspiration for this representation technique comes from mediaeval transoblique perspectives. Just as in Hans Boblinger's contemporary drawing for the Hospital of Eslingen, Martini's octagonal or hexagonal fortresses in the Magliabecchiano (Fig. 7), include frontal curtains depicted in transoblique perspective and lateral curtains in military perspective.

Anyhow, Bois (1983: 150) has remarked that "such drawings are not technically exact in the modern sense". The draughtsman does not represent precisely, in accordance with the laws of parallel projection, the bases of the lateral conical surfaces in the bastions; the end generatrices are not tangent to the base of the cone (see Figs. 4, 5). Such errors result from the lack of understanding of the properties of cylindrical projection. Thus, we cannot speak of precise military perspectives, but rather, as Arnau has stressed, intuitive axonometrics: "Frequently, Di Giorgio uses impromptu, intuitive axonometrics, with a good sense of representative efficiency: he means to put forward the evidence of the object, rather than appeal to visual imagination, and he usually succeeds" Arnau (1988: III-115).

For example, the drawing in Magliabecchiano fol. $62 \mathrm{v}$ reproduces rather precisely the shape of the plan, an heptagon; in the pentagonal shape in fol. 64, the error is more noticeable; the layout of the hexagonal fortress in fol. $67 \mathrm{v}$ is remarkably precise, while the central circles are depicted quite correctly, in accordance with the principles of military perspective. However, this last drawing departs clearly from these principles in the upper part of the central tower: while the general shape reproduces the plan without significant deformations, and thus complies with the rules of military perspective, the central tower is depicted using an intuitive kind of bird's eye linear 
Fig. 6 Francesco di Giorgio Martini (1490b). Military perspective of a pentagonal fortress with bastions. Codex Magliabecchiano fol. 64.

Reproduced by permission of Biblioteca Nazionale Centrale, Firenze

Fig. 7 Francesco di Giorgio Martini (1490b). Military perspective of a hexagonal fortress with bastions, combined with a bird's eye view of the central tower. Codex

Magliabecchiano fol. $67 \mathrm{v}$. Reproduced by permission of Biblioteca Nazionale Centrale, Firenze

perspective (see Fig. 5). The same thing occurs in the fortress depicted in fol. 65 in the Magliabecchiano. That is, in both drawings, two different perspective solutions are used in a hybrid drawing. Such solutions were still acceptable in Serlio's period; only 
Fig. 8 Francesco di Giorgio Martini (1480a). Plan of an octagonal sawtooth fortress. Codex Saluzziano, fol. 5. Reproduced by concession of the Ministry of Cultural Assets and Activities and Tourism of Italy. Biblioteca Reale, Torino

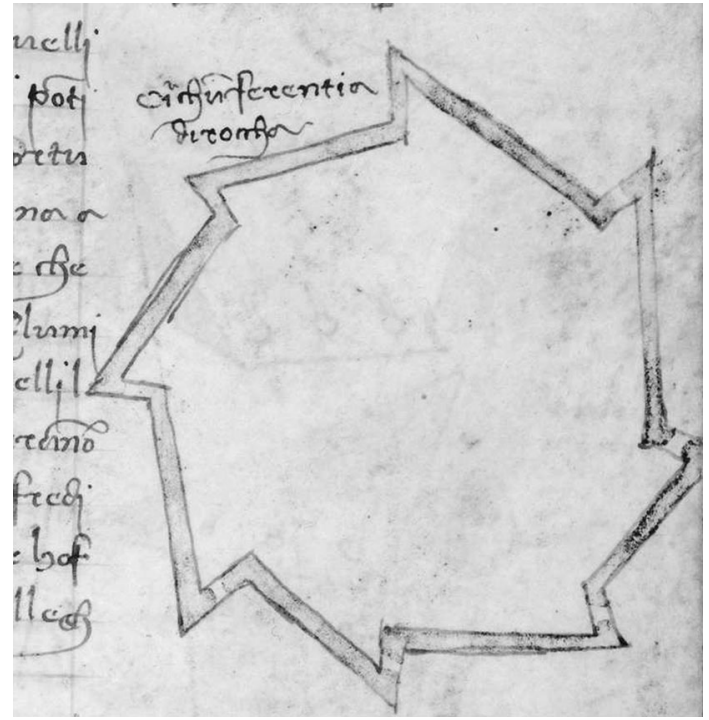

Fig. 9 Francesco di Giorgio Martini (1490b). Military perspective of an octagonal sawtooth fortress. Codex Magliabecchano fol. $61 \mathrm{v}$. Reproduced by permission of Biblioteca Nazionale Centrale, Firenze

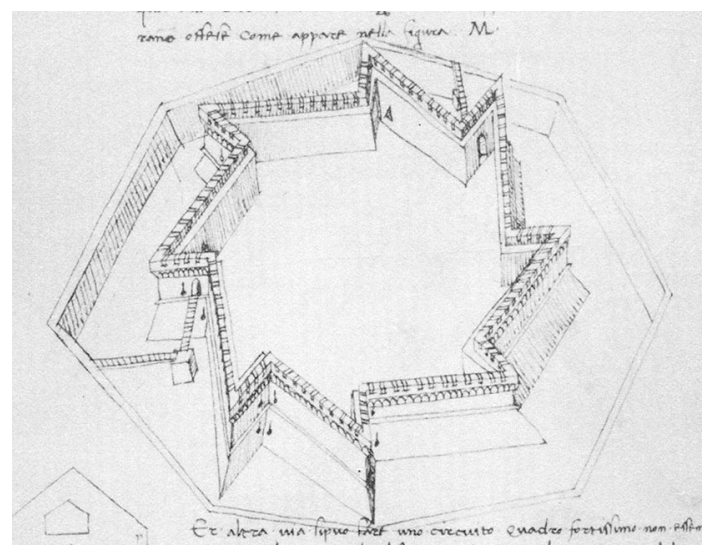

in Palladio's times were they eschewed for pure orthographic drawing or perspective. In contrast, in pure bastion solutions, without central tower or high constructions, Martini uses a rather correct military perspective. This graphical device, which represents the plan without deformations, offers a fundamental advantage, since it allows Martini to represent this new system of fortifications quite clearly.

Taking into account that Martini uses linear perspective correctly in interior drawings of civil architecture, we should conclude that the use of military perspective by Martini, and even his errors, are not the result of a lack of knowledge of the laws of linear perspective, but rather of Martini's determination to show clearly the new features of the fortification designs of the period to the reader of his treatise, using a new means of representation, particularly fitting to depict the horizontal layout of curtains and bastions. Thus, the errors in these representations must be considered as the inevitable results of a technique that was not yet systematized in this period. 


\section{Peruzzi, Zanchi and Corneweyle}

The success of Martini's new graphical techniques is attested by a number of treatises in the sixteenth century. The manuscript by Peruzzi (c. 1520) in the Accademia delle Belle Arti in Florence, mentioned earlier, reproduces Martini's fortresses and bastions, using the same graphical means: bird's eye perspectives for high-rise castles and military perspectives for bastion-based systems, using shading, but no cast shadows or dimensions (Fig. 8). Technically, it does not bring forward any innovation when compared with Martini.

The reception of Martini's solutions in other treatises is attested also by the publication history of the highly successful treatise by Zanchi (1554), Del modo di fortificar le città. Rather than a thick treatise such as Martini, it is a short manual which explains clearly a number of solutions for the fortification of cities with bastions in their vertices. Although written probably in the decade of 1520 , it was published in 1554; it enjoyed instant success, with several editions in Italian and translations into several languages. Most of the bird's eye perspectives (Fig. 10) in the first edition were replaced by military perspectives in later editions.

A French translation of Zanchi's treatise appeared in 1556 in Lyons, under the name of François de la Treille, with the title La manière de fortifier villes, chasteaux, et faire autres lieux forts; this book is the first one published in France about fortifications (De la Treille 1556). In turn, 3 years later it was translated from French into English by Corneweyle (1559), in a manuscript preserved in the British Library, which has not been published until the twentieth century. According to Corneweyle, the French version was not only translated, but also corrected and enlarged. This is true not only for the text, but also for the plates. The Italian original includes seven different drawings - three square fortresses with bastions in the corners and two octagonal systems - depicted in four plates. All of them are represented in bird's eye perspective. Biddle (1972: iv) remarks that "La Treille reproduces the seven figures in Zanchi in the same order with the same numbers, adding two further plates, with numbers $7 \mathrm{a}$ and 8 ; the text does not mention this last one".

Corneweyle included no less than eleven figures. Those on fols. 27, 28 and 28v are bird's eye perspectives. In contrast, four plates depict fortresses using a plan and a perspective for each one, but in these later plates Zanchi's bird's eye perspective has been replaced with military perspectives.

The remaining four plates are not taken from Zanchi; they depict two fortresses in plan and military perspective. Quite significantly, Corneweyle's military perspectives have not been drawn raising heights from the plan, since the crowning of each fortress, drawn with remarkable precision, is smaller than its base. There are no dimensions or graphical scale. In these carefully drawn schemes the curtains are hatched, emphasizing the three-dimensional image.

Thus, the successive re-elaborations of Martini's and Zanchi's treatises show the gradually increasing precision in the representation of military architecture over the course of the first half of the sixteenth century. In contrast, in the second half of the century and particularly in the seventeenth century, military perspectives escape from this narrow specialist field, opening into a wider realm of lavishly illustrated books for the general public, showing the broad diffusion of this graphical device. 


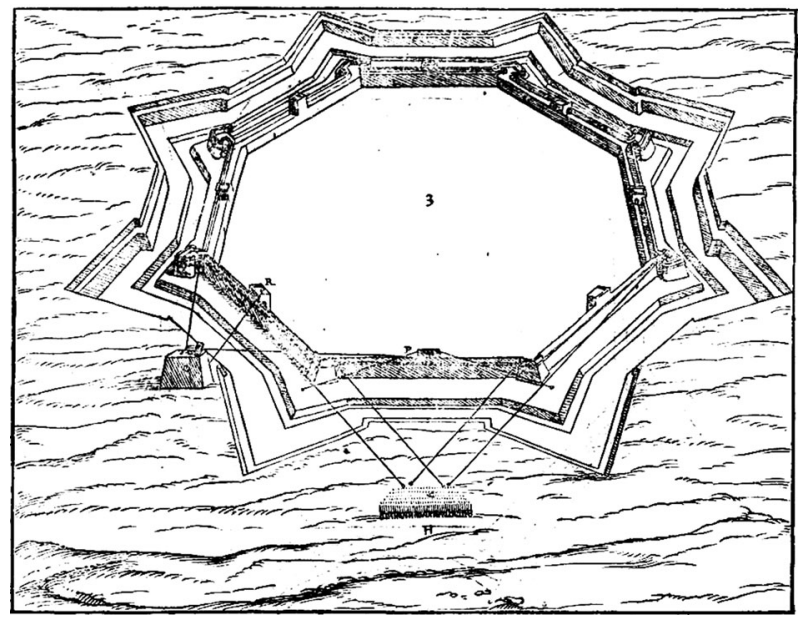

Fig. 10 Giovanni Battista de Zanchi (1554: 21). Bird's eye perspective of a fortress. Dell' modo de fortificare la città

\section{Lorini and Hondius}

None of the three authors Martini, Zanchi and Corneweyle explain the rules of this new representational method; we can only surmise the existence of a system of graphical rules by induction. Such rules were explained for the first time by Lorini (1596) in Delle Fortificationi, dedicated to King Philip II of Spain. The twelfth chapter of the first of its five books is entitled "Practical book about drawing in perspective all things that rise from the soil", and explains the practice of "the most common perspective", the term that the author uses when dealing with military perspective.

Lorini, a Florentine nobleman, was born around 1540. A protégé of Cosimo I de Medici, he devoted himself from his youth to the study of military architecture. From 1568 on, he was involved in the French Wars of Religion, on the Catholic side. In 1580 he came back to Italy as an engineer for the Venetian Republic, working on a number of important fortifications in Brescia and the Dalmatian Islands. In his treatise, with editions in 1596 and 1609, he endeavoured to explain the practical knowledge he had gathered in his long experience as an engineer. In particular, his extensive field training had taught him the different applications of drawing in military engineering, as well as the crucial importance of its correct execution and interpretation. He quotes Archduke Charles of Habsburg, who boasted that "he was not to be deceived by those that showed him the drawings of the villages that he was to pass with the armies or the plans of the fortresses that were to be built" (Lorini 1596: 32-33). As a consequence, Lorini encourages his readers, in particular military engineers, to "learn to draw since drawing is quite useful in all professions and in particular for those that must commission or build large constructions ..." (Lorini 1596: 32-33). Lorini uses plans and "the most common perspective", that is, military perspective, in order to depict fortresses in his treatise, in particular bastion systems: 
Since drawings in perspective of fortresses or other things are frequently prepared in order to understand a construction, you should know that it is sufficient to follow the practice of the most common perspective, which is not only useful, but also quite necessary in fortification, as in other things (Lorini 1596: 32).

He uses a simple example to explain the construction of these perspectives:

To begin with all that has been said about drawing constructions or any other thing in perspective, I should use as an example a wall made with several angles, that we will use as a general rule for any other that we should draw (Lorini 1596: 33).

Next, he describes in half a page his procedure: he draws the perimeter of the upper part of the wall, including its thickness, and then he draws vertical lines going down from the corners of the wall (Fig. 11).

Lorini interprets his "common perspective" as a kind of linear perspective with a raised point of view: "you can see its height from different points, that is, from the inside and the outside, as if it were really constructed in the field, so that the eye of the observer is so high that he can see the inside of the fortress" (Lorini 1596: 34). This interpretation appears for the first time in Lorini's treatise; it will reappear many times from this moment on. Also, Lorini suggests for the first time that military perspective allows measuring from the drawing: "And when shown in whole or in part, this wall is constructed according to measurements" (Lorini 1596: 34). In fact Lorini includes a graphical scale not only in his plans, but also in his military perspectives, in contrast to Martini or Corneweyle.

With such a short description of Lorini's technique, it is not easy to ascertain if his particular procedure originated in Italy or if he became acquainted with it during his stay in Flanders and France. Anyhow, the same method is explained in Hondius (1625) (1563-1650) Instruction en la science de perspective, published in The Hague. The author was a disciple of Jan Vredeman de Vries (1604-1605); he prepared the etchings for de Vries's perspective treatise (as well some plates for the well-known Civitates Orbis Terrarum (Braun et al. 1572-1617) and for Marolois's Optica sive perspectiva (Marolois 1633). It is easy to surmise that he knew the technique used in the parallel perspectives in Civitatis.

At the beginning of his Instruction, Hondius states his intentions: "I have tried in this small work to present and explain all this perspective science in such a short and easy manner as possible" (Hondius 1625: 1). His book includes 43 plates dealing with linear perspective, with explanations. At the end, Hondius includes a plate with the mention: "To finish, I have included here this last plate, representing geometrical depth" (Hondius 1625: 29). Next, he goes on to explain a procedure that is essentially the same as the one explained by Lorini 30 years earlier, drawing lines downwards from the perimeter of a figure and measuring heights along these lines. However, he does not restrict himself to fortresses; he takes a number of different polygons and represents them in military perspectives. He even explains how to proceed when applying this procedure to circles, ovals or any other geometrical figure, just as if they were fortifications (Fig. 12). 


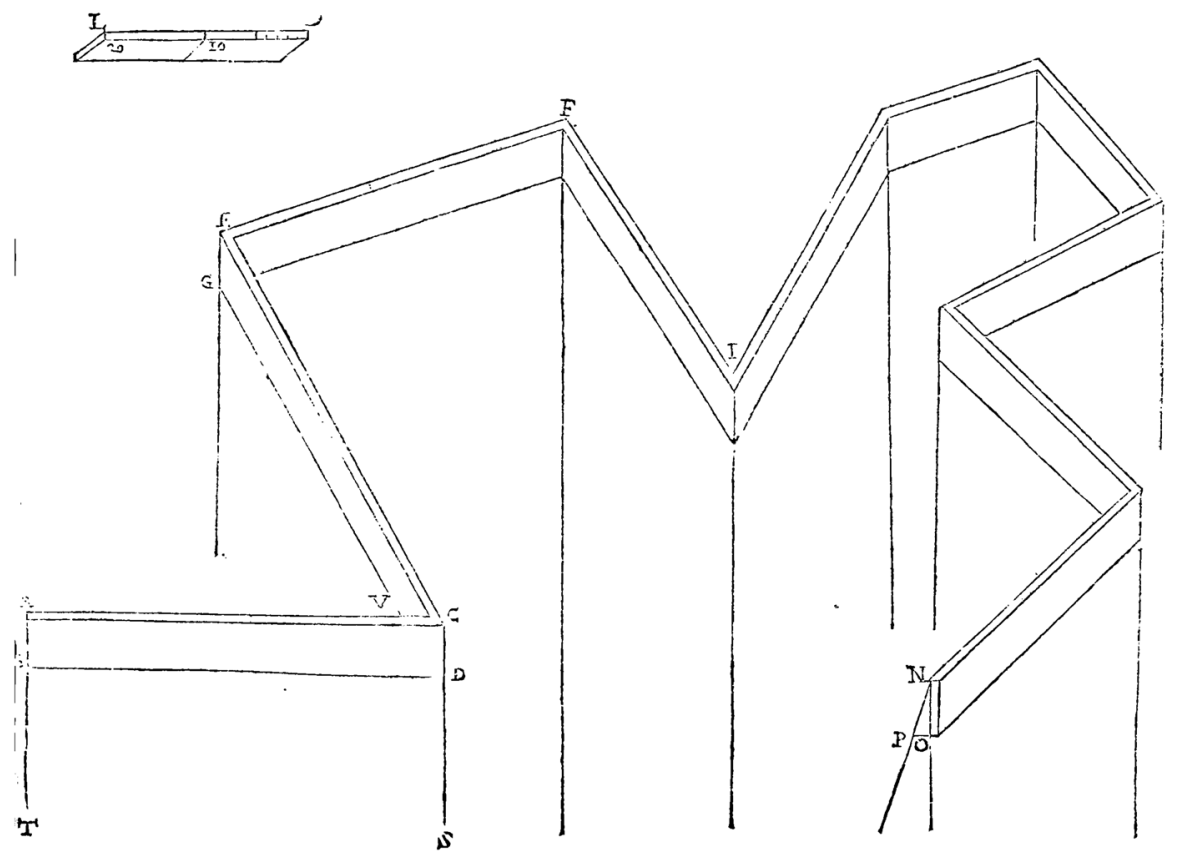

Fig. 11 Buonaiuto Lorini (1596: Book I: 33). Method for drawing the military perspective of a fortress. Delle fortificationi

He suggests that the reader include shading in these drawings, although he does not make clear how this should be done. Thus, Hondius's explanation is as short and economical as Lorini's and is only useful for the representation of simple volumes. However, he applies it to a greater number of examples and, for the first time, takes this technique outside the field of military architecture.

\section{The Treatise Attributed to Du Breuil}

This expansion of military perspective beyond the borders of the realm of fortification drawing was completed in the treatise generally attributed to Jean Du Breuil (1602-1670). ${ }^{1}$

\footnotetext{
1 This attribution poses a number of problems. First, the title page of this treatise includes the name $L a$ perspective practique necessaire a tous peintres, graveurs, sculpteurs, architectes ... par un Parisien Religieux de la Compagnie de Iesus, (1642) and the copy in the National Library of France is inscribed as "Ex dono Jean du Breuil soc. Jesus". Besides, a number of works on perspective of the period, in particular those by Bosse (1668) attribute the work to Jean Du Breuil, a son of a famous family of printers that left the trade for the Society of Jesus, where he was entrusted the supervision of the Novitiate in Dijon. Although this attribution was rejected in the 19th century by Noel-Germinal Poudra (1864: 271), arguing that the proofs for Du Breuil's authorship were scant, it is generally accepted now. However, this issue lies outside the scope of this article, so we shall refer to the author of the treatise as Du Breuil only for the sake of simplicity.
} 


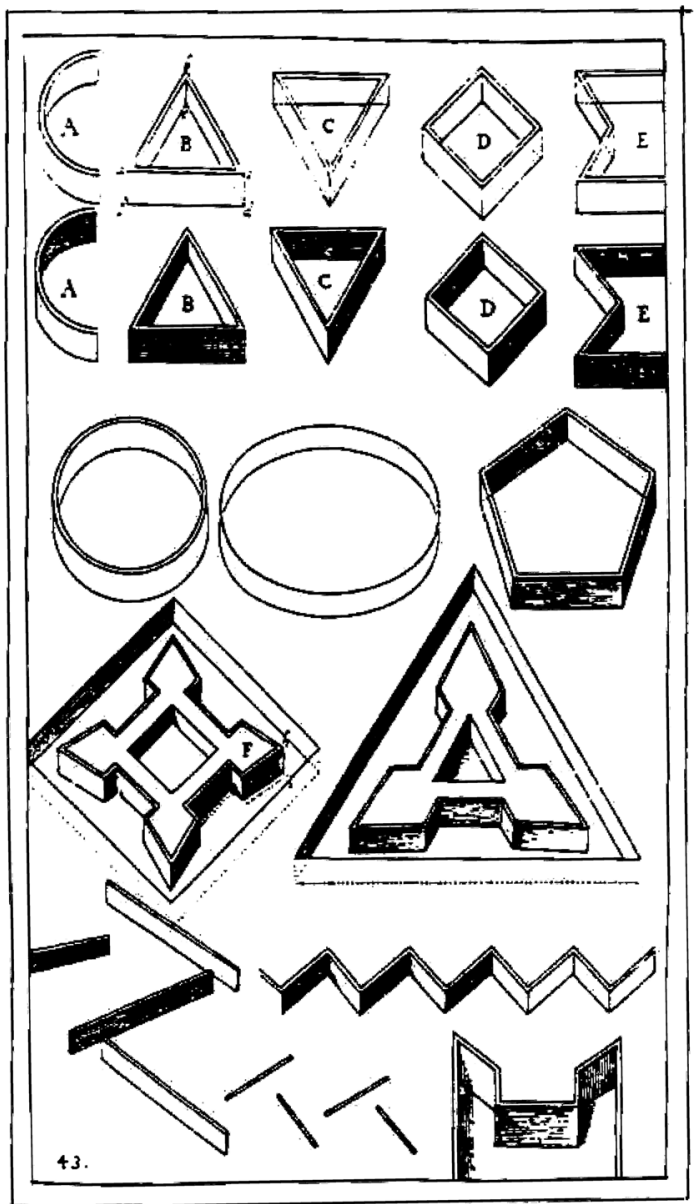

Fig. 12 Hendrik Hondius (1625). Method for drawing military perspectives of fortresses and other shapes. Instruction en la science de perspective: plate 43

The first volume of the treatise (1642), tries to summarise a large body of material taken from many authors, in particular Serlio (1545), Cousin (1560), Vignola and Danti (1583) and Desargues (1636), in a comprehensive treatise on linear perspective. Du Breuil did not understand correctly Desargues' sophisticated method, based on different scales, and he was violently rebutted by Desargues (1647), who accused him of plagiarism.

Except for this point, Du Breuil managed to put together a clear explanation of mainstream perspective methods for the general public; as a result, this first volume enjoyed a wide circulation. By contrast, the second and third volumes (Du Breuil 1647, 1649), respectively, devoted to a number of applications of linear perspective, did not stir much interest. However, it is worthwhile to remark a passage in the second volume, where Du Breil shows his dislike for bird's eye perspective and 
military perspective. When talking about la perspective regardée de haut en bas, that is, bird's eye linear perspective, Du Breuil states that:

all that can be said about such perspectives is that they are only pleasant from the point and the distance chosen ... since it is ridiculous to see trees with their trunks bundled and the roofs of the houses bigger than their lower parts ( $\mathrm{Du}$ Breuil 1647).

However, in Du Breuil's opinion, such linear perspectives are to be preferred to military perspectives:

I have included a fortification in order to show that the most difficult pieces in ordinary perspectives are not so difficult in these ones; this makes me believe that the engineers will use them more easily than the ones called military perspectives, which do not show the clearly the interior of the fortress when there is anything hidden by the elevation of the walls and other elements in the forefront, while in this [bird's eye] perspective nothing is hidden and the whole elevation is seen because the point of view is placed in the middle, or at least inside the fortress (Du Breuil 1647).

These remarks are the only ones in the whole three volumes of the first edition of Du Breuil's treatise dealing with military perspective. Anyhow, in the second edition of the first volume, published in Paris in 1651, Du Breuil added a short final chapter on military perspective, explaining that "the last and seventh chapter deals with military perspective, that is, geometrical elevations, prepared raising whatever you wish over a geometrical plan, without the need of any ordinary perspective". He also makes clear that his disdain for military perspective has not changed; he includes military perspective in his treatise only to please some of his readers:

It would have been a lack of courtesy on my part not to include this short treatise on military perspective, taking into account the petitions of those who can ask me that. However, in my opinion, this method does not belong in the field of perspective. It is an exaggeration to give it this name, which reasonably cannot be given to it, since nothing is done with the principles nor the rules of this science [of perspective], that involves always a high or low horizon, concentric rays and diminutions on both distances (Du Breuil 1651).

So, Du Breuil understands that military perspective is just a set of geometrical constructions, not a true science like linear perspective, and thus he proposes a new name for this graphical method: "I would rather change this name of military perspective to geometrical elevations, since it involves only perpendicular constructions or ramparts starting from geometrical plans" (Du Breuil 1651). It should be stressed that, in this context, the term "geometrical" alludes to the plan, which is known as plan geometral, that is, "geometrical plane", in such perspective treatises as the one by Cousin (1560), in contrast with the "perspective plane". Also, the term "geometrical elevations", does not allude to vertical projections but, rather, to the fact that $\mathrm{Du}$ Breuil is going to construct his military perspectives from the ground up, in contrast with Hondius (1625), who starts from the top of the wall and, quite appropriately, speaks about "geometrical depth". 
In any case, his general disdain for this method does not prevent him from appreciating its simplicity and other advantages:

Although this method does not offer the exactitude and precision of true perspectives, it is pleasant and easy to practice ... anybody who can draw a plan can construct an elevation, using only a scale in order to construct lengths or heights, both for the elements that rise from the ground and the ones that go down (Du Breuil 1651).

He also finds another advantage: military perspective does not involve a deformation of horizontal figures and angles, and it does not cause foreshortening:

In this method, elevations do not change at all the angles, that remain always as in the plan, and the plan does not adopt any figure other than the geometrical plan that stays in the upper part of the elevation when the heights are the same, as in the foot where they are elevated (Du Breuil 1651).

That is, Du Breuil explains a number of advantages not only of military perspective but of parallel projection in general: an easy way to construct a threedimensional image that furnishes measurements, "which is extremely useful for any noblemen, engineers, gentlemen, officers and anybody that want to explain a town, a stronghold, a fortress, a fort, a citadel, a castle, o similar things" (Du Breuil 1651). As we have seen, although Du Breuil's term, "geometrical elevations" may seem striking at first sight, it is quite coherent with his method; by contrast with Lorini or Hondius, he instructs the reader to draw vertical lines upwards starting from the base of the object he wants to draw.

Du Breuil explains the construction of such "elevations" in twelve pratiques or tutorials. The first one comes under the heading "De l'echelle a mesurer les plans et les elevations geometrales", that is, "About the scale used to measure the plans and the geometrical elevations", involving the study and construction of the different scales used to measure and draw the plans, elevations, and military perspectives.

From this point on, he represents in military perspective a number of different prismatic shapes-pyramids, cones and cylinders-with their bases on a horizontal plane, which are represented as circles (Fig. 13). In tutorial VII, he also represents a sphere, using a circle: "Spheres and balls are and must be absolutely round, so that they must be seen as a perfectly round circle from any angle; thus, to draw its plan or elevation you must draw a circle" (Fig. 14). This does not follow the rules of nineteenth-century oblique axonometrics, based on oblique cylindrical projection; in fact, spheres should be represented as ellipses in military or cavalier perspective. Quite to the contrary, Du Breuil is using an empirical procedure that is not based on projection and the conventions arising from it.

The last tutorials involve not only a number of fortresses, but also everyday objects such as tables and chairs (Figs. 15, 16). That is, Du Breuil plays homage to the military origin of this graphical technique, but he goes much farther than Martini, Lorini or Hondius, turning a specialist procedure in a general graphical method.

As his predecessors, Du Breuil does not apply cast shadows in military perspective, but he illuminates intuitively the faces of his figures, trying to accentuate the three- 
dimensional effect of this kind of representation, with a zone of maximum lighting in front of a virtual light source. Quite significantly, this technique is applied to the sphere; in contrast, the circle, represented only in a horizontal plane, is uniformly hatched, in order to differentiate it from the sphere, since both are represented by simple circles. Ironically, the application of cast shadows to military and transoblique perspective was to be explained by Abraham Bosse, a pupil of Desargues and, we may surmise, a fierce enemy of Du Breuil, in Traité des pratiques geometrales et perspectives (Bosse 1665; see also Sakarovitch 1997: 83-85).

Thus, the text of Du Breuil gives, for the first time, a full explanation, albeit empirical and with some errors, of the construction of parallel perspectives, before its systematization in the nineteenth century. This is not surprising. In the seventeenth century, the possibilities of linear perspective, including complex problems such as anamorphoses, shades, shadows and reflections, all of them covered in Du Breuil's text, were explored in depth. Parallel perspective was not the object of such a detailed study, in part due to its own simplicity, in part owing to the disdain of such theorists as Du Breuil, which is still mirrored in late-twentiethcentury writers such as Sakarovitch (1997: 83-85). As we have seen, the Jesuit theorist understood military perspective not as a complex science as linear perspective, but rather as a simple means to represent towns, fortresses or everyday objects in a simple and convenient way.

\section{Coda: Farish, Pohlke, Choisy and Le Corbusier}

This conception of military or parallel perspective as a set of rules and not a science explains a puzzling fact. From the very start, in Alberti's De Pictura, linear perspective was explained in terms of projection and intersection. Orthographic projections took form in the Late Middle Ages on a purely empirical basis; however, since the late sixteenth century, treatises such as Rojas y Sarmiento (1550), Aguillon (1613), Accolti (1625) or De la Faille (c. 1640), present them as parallel projections, first in the field of cartography and later on as a general method. In contrast, military and cavalier perspectives were not explained as parallel projections until the nineteenth century, after a rather strange turn of events.

In 1822 William Farish published "On Isometrical Perspective", a short paper that put forward a rather far-fetched idea. Rather than using horizontal and vertical projectors, as Monge (1798) had done in his Descriptive Geometry following the tradition of Aguillon and Accolti, Farish used a set of projectors that were parallel to the diagonal of a cube and a projection plane that was orthogonal to such projectors. Since all edges of the cube form the same angles with the diagonal, and also with the projection plane, the projections of all edges were shortened in the same proportion, namely $\sqrt{ } 2 / \sqrt{ } 3$, while the angles between the projections of the edges must be equal as a result of the symmetry of the figure. This allowed him to use the edges as axes to construct an axonometry (Farish 1822). Later on, German writers tampered with the angles between the axes and the projection plane, arriving to other variants of axonometry, such as dimetric and trimetric projection (see Càndito 2003). 


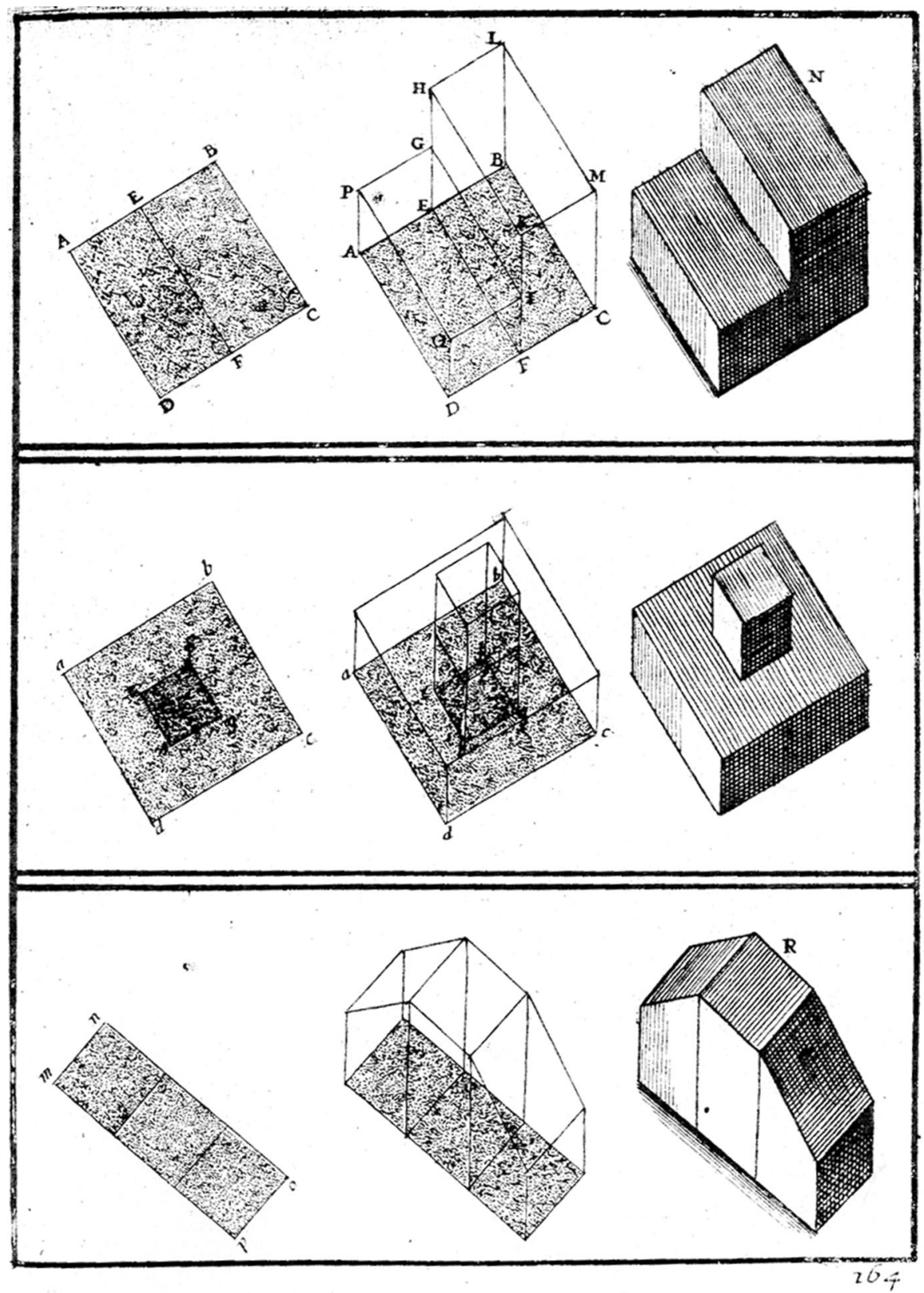

Fig. 13 Jean Du Breuil, attr (1642). Method for drawing different shapes in military perspective. $L a$ perspective pratique ..., 2nd ed., vol. I, p. 164

The idea did not appeal the French; quite possibly they understood it as a form of British invasion. The old idea of cavalier and military perspective was still extant, but it had to overcome much prejudice. In fact, Monge had torn out the sheets in 


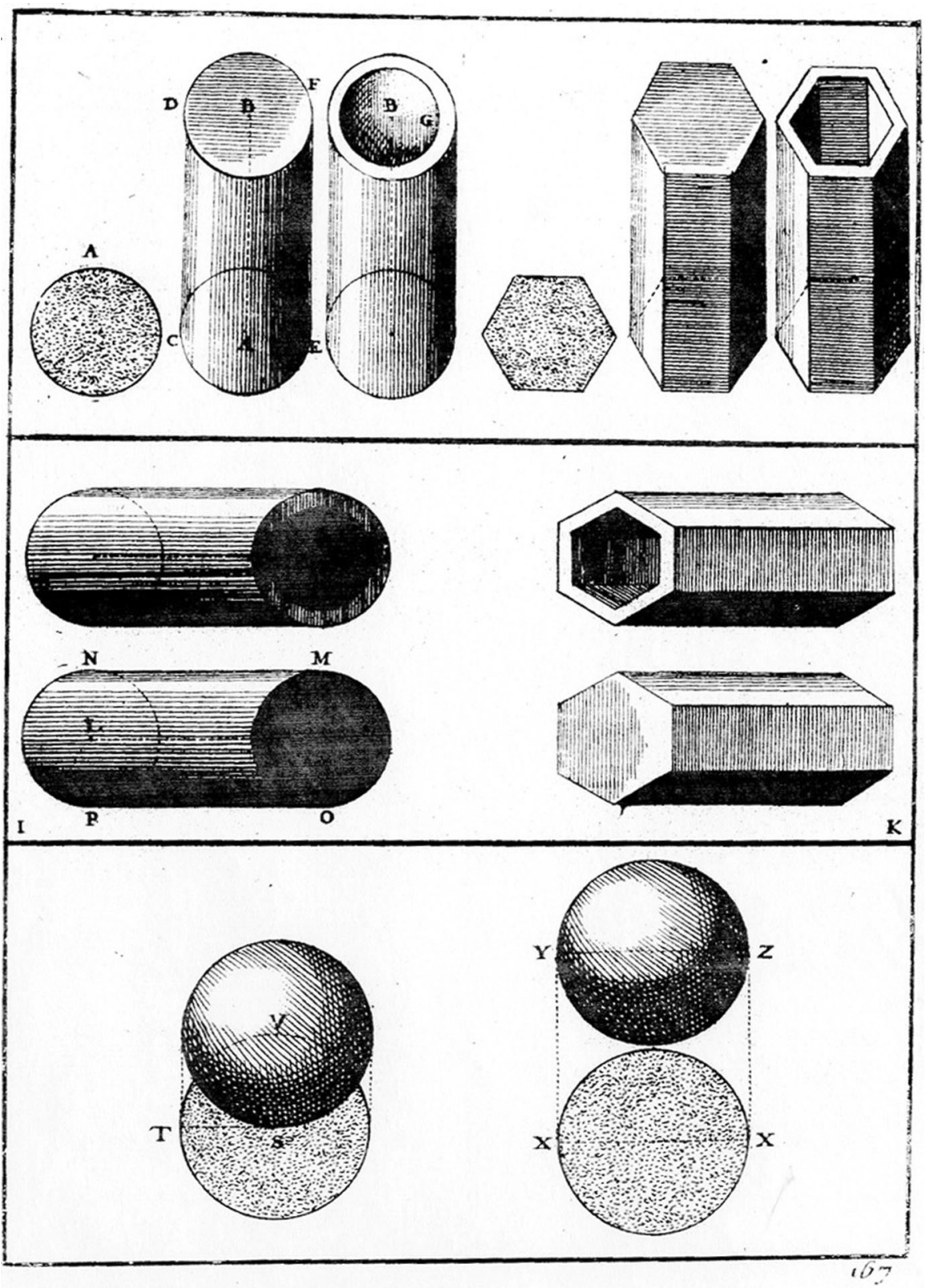

Fig. 14 Jean Du Breuil, attr. (1642). Method for drawing prisms, cylinders and spheres in military perspective. La perspective pratique ..., 2nd ed., vol. I, p. 176

Jean Baptiste de la Rue's stonecutting treatise (1728) used by his students in order to prevent them from seeing De La Rue's cavalier and military perspectives (Sakarovitch 1997: 333). The legality of these graphical procedures was not fully 


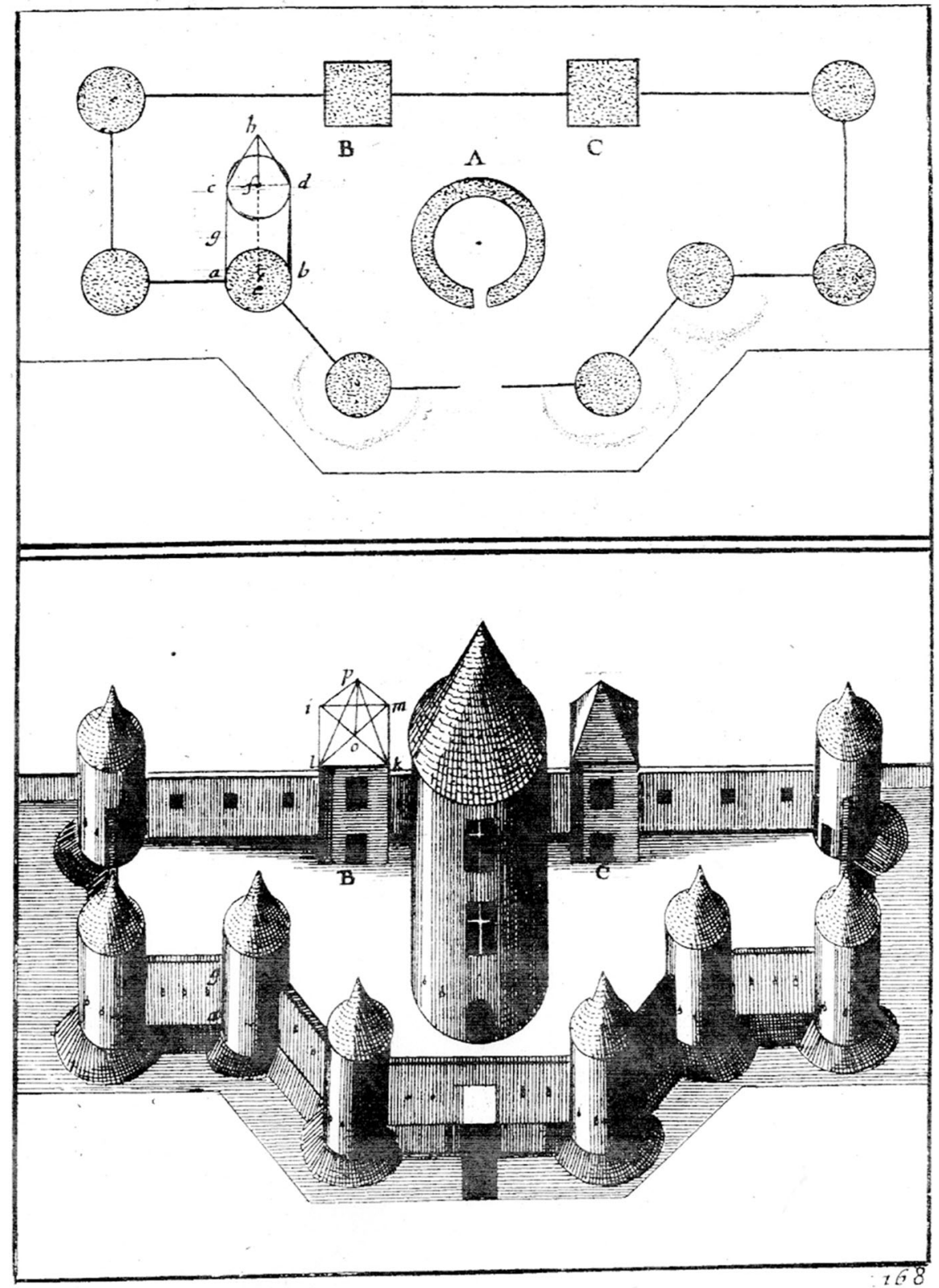

Fig. 15 Jean Du Breuil, attr. (1642). Method for drawing a fortress in military perspective. $L a$ perspective pratique ..., 2nd ed., vol. I, p. 168

established until Pohlke's theorem was demonstrated. It states that three segments of arbitrary length which are drawn in a plane starting from any point under arbitrary angles form a parallel projection of three equal segments constructed from the 


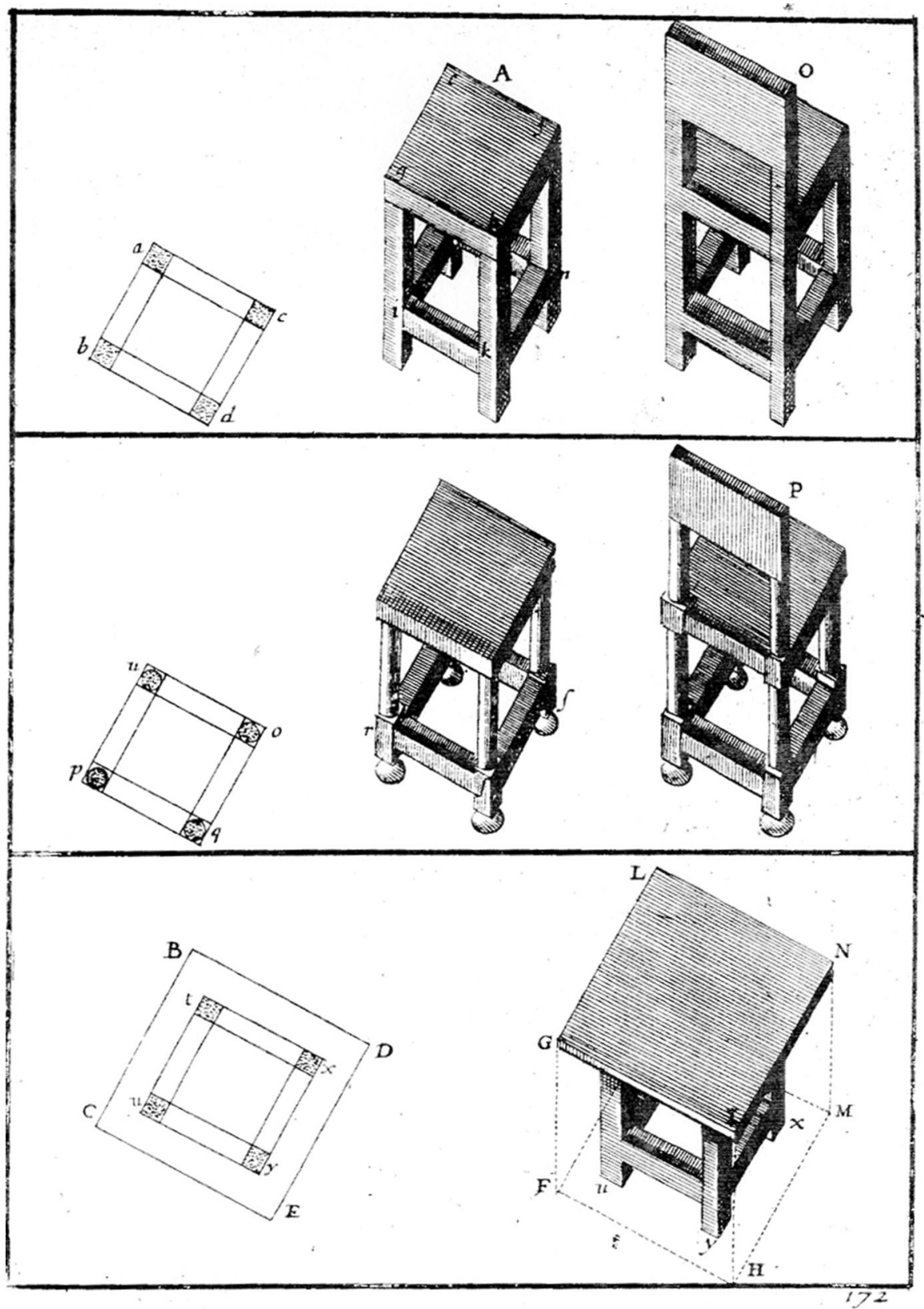

Fig. 16 Jean Du Breuil, attr. (1642). Method for drawing tables and chairs in military perspective. $L a$ perspective pratique ..., 2nd ed., vol. I, p. 172

origin of three perpendicular lines, provided that not more than one segment or one angle is null. All this allows constructing an axonometric drawing with arbitrary angles and reduction coefficients, and still being sure that such drawing is equal or 
similar to an oblique projection. The proof of the theorem was not simple, and in fact it was published more than a decade after Pohlke had stated the theorem. It is somewhat striking that the legality of cavalier and military perspective was dependent on Pohlke's theorem, since both are particular instances of oblique projections, and it can be demonstrated quite easily that both are projections; thus, Pohlke's theorem is only significant for the general case of axonometry, the socalled 'ordinary axonometry', that offers little or no advantages and is rarely used today. But the fact is that cavalier and military projections were only fully accepted in the literature of descriptive geometry after Pohlke's theorem, dubbed in some occasions as "the fundamental theorem of axonometry", was demonstrated; Gino Loria (1921) devoted the section on oblique axonometry of his classic Storia della Geometria Descrittiva almost exclusively to Pohlke's theorem.

A significant detail shows that such issues were not merely theoretical. In his Art de bâtir chez les Romains, (Choisy 1873; see also Rabasa 1999: xxiv-xxv) remarked that some of his well-known drawings are not projections; this striking assertion can only be understood taking into account that the proof of Pohlke's theorem had not been published at this moment. Later on, in his Historie de l'Architecture, Choisy (1899) used many inverted military perspectives, making good use of a fundamental property of such graphical technique: the preservation of the shape of horizontal figures allowed him to show quite clearly the relationship between the plan and the vaulting. Le Corbusier, Sartoris and other architects of the Modern Movement reversed Choisy's system and went back to Martini's classical military perspective to stress, not the interior space of their villas, but rather the connections between the overall layout of the building and the resulting volume. Anyhow, speaking more generally, Martini, Choisy and Le Corbusier used military perspective in basically the same way: they put to good use the main feature of this method, the preservation of the plan, in order to stress the general organization of their designs.

\section{References}

Accolti, Pietro. 1625. Lo inganno de gl'occhi, prospettiua pratica ... Firenze: Pietro Cecconcelli.

Aguillon, P. François d'. 1613. Francisci Aguilonii e societate Iesus Opticorum libri sex, Philosophis iuxta ac Mathematicis utiles. Antuerpiae: Moretus.

Alberti, Leon Battista. 2004. On Painting. Cecil Grayson, trans. London: Penguin Classics.

Arnau, Joaquín. 1988. La teoría de la arquitectura en los tratados. Madrid: Tebar-Flores.

Benevolo, Leonardo. 2003. Storia dell'architettura del Rinascimento. Roma-Bari: Laterza.

Biddle, Martin. 1972. Introduction. In Zanchi, Giovani Battista. The manner of fortification of cities, townes, castelles and other places ... translated, ed. Robert Corneweyle. Gregg International Publishers.

Bois, Ive-Alain. 1983. Metamorphoses of Axonometry. In Het Nieuwe Bouwen: De Stijl: De Nieuwe Beelding in de architectuur. ed. C. Boekraad et al Neo-Plasticism in Architecture. 146-160. Delft: Delft University Press.

Bosse, Abraham. 1665. Traité des pratiques géométrales et perspectives enseignées dans l'Académie royale de la peinture et sculpture. Paris: Bosse.

Bosse, Abraham. 1668. Lettres écrites au Sr Bosse, graveur, avec ses réponses sur quelques nouveaux traittez concernans la perspective et la peinture. Paris: Bosse.

Braun, Georg, et al. 1572-1617. Civitates Orbes Terrarum. Antuerpiae. 
Càndito, Cristina. 2003. Le proiezioni assonometriche. Dalla prospettiva isometrica all'individuazione dei fondamenti del disegno assonometrico. Firenze: Alinea.

Càndito, Cristina. 2009. Il Disegno delle Fortificazioni nei Trattati Rinascimentali In Le torri costiere dell'imperiese. Riflessioni sulla conoscenza, la valorizzazione e il recupero delle strutture difensive e di avvistamento. 34-38. Genova: Graphic Sector.

Choisy, Auguste. 1873. L'art de bâtir chez les romains. Paris: Ducher.

Choisy, Auguste. 1899. Histoire de l'Architecture. Paris: Gauthier-Villars.

Corneweyle, Robert. 1559. "The keye of the Treasorie: or the manner of fortification of cities, townes, castelles, and other places, ... not onlye translated oute of Frenche into the English tonge but also corrected and augmented by Robert Corneweyle, ..." MS 28030. London. British Library.

Cousin, Jean. 1560. Livre de perspective. Paris: Iehan le Royer.

Desargues, Girard. 1636. Exemple de l'une des manieres universelles du S.G.D.L. touchant la pratique de la perspective sans emploier aucun tiers point, de distance ny d'autre nature, qui soit hors du champ de l'ouvrage. Paris: Jacques Dugast.

Desargues, Girard. 1647. Six erreurs des pages 87. 118. 124. 128. 132. \& 134. du livre intitulé La Perspective practique. Paris: Melchior Tavernier-Francois Langlois, dit Chartres.

De la Faille, Jean-Charles de. 1640 c. "De la arquitectura”. Madrid. Biblioteca del Palacio Real. Ms. II/ 3729.

De la Rue, Jean-Baptiste de. 1728. Traité de la coupe des pierres où par méthode facile et abrégée l'on peut aisément se perfectionner en cette science. Paris: Imprimerie Royale.

De la Treille, François. 1556. La manière de fortifier villes, chasteaux, et faire autres lieux fortz. Lyon: par Guillaume Rouillé.

Du Breuil, Jean, (attr.) 1642. La perspective practique, neccesaire a tous Peintres, Graveurs, Scultpteurs, Architectes, Orfevres, Brodeurs, Tapissiers, et autres se servant du dessin ... Par un Parisien, religieux de la Compagnie de Jesus. Paris: Melchior Tavernier-Francois L'Anglois, dit Chartres.

Du Breuil, Jean, (attr.) 1647. Seconde partie de la Perspective pratique qui donne une grande facilité à trouver les apparences de tous les corps solides ... Par un religieux de la Compagnie de Jesus. Paris: Veuve de François L'Anglois, dit Chartres.

Du Breuil, Jean, (attr.) 1649. Troisiesme et derniere partie de la Perspective pratique. Ou se voient les beautez \& raretez de cette science. Avec les methodes pour les pratiquer sur toutes sortes de plans ... Par un religieux de la Compagnie de Jesus. Paris: Veuve de François L'Anglois, dit Chartres.

Du Breuil, Jean, (attr.) 1651. La perspective practique, neccesaire a tous Peintres, Graveurs, Scultpteurs, Architectes, Orfevres, Brodeurs, Tapissiers, et autres se servant du dessin. 2nd ed. Paris: Veuve de François L'Anglois, dit Chartres.

Farish, William. 1822. "On Isometrical Perspective". Cambridge Philosophical Transactions, 1.

Hondius, Hendrik. 1625. Instruction en la science de perspective. Den Haag.

Loria, Gino. 1921. Storia della geometria descrittiva dalle origini sino ai giorni nostri. Milano: Ulrico Hoepli.

Lorini, Buonaiuto. 1596. Delle fortificationi. Venezia.

Lotz, Wolfgang. 1977. The Rendering of the Interior in Architectural Drawings of the Renaissance. In The Architecture of the Italian Renaissance, ed. Wolfgang Lotz, 1-65. Cambridge (Mass.): MIT Press,.

Maggi, Girolamo, and Giacomo Castriotto. 1564. Della fortificatione delle città. Venetia: Rutilio Borgominiero.

Maltese, Corrado. 1967. Introduzione. In Trattati di architettura, ingegneria e arte militare, ed. Francesco Di Giorgio Martini, i-xviii. Milano: Il Polifilo.

Marolois, Simon. 1633. Optica sive perspectiva pars prima. Amsterdam.

Martini, Francesco di Giorgio. c. 1480a. "Trattato di architettura, ingegneria e arte militare". Codex Saluzziano 148. Torino: Biblioteca Reale.

Martini, Francesco di Giorgio. c. 1480b. "Trattato di architettura, ingegneria e arte militare". Codex Ashburnhamiano 361. Florence: Biblioteca Laurenziana..

Martini, Francesco di Giorgio. c. 1490a. "Trattato di architettura civile e militare". Codex Senese S. IV. 4. Siena: Biblioteca Nazionale.

Martini, Francesco di Giorgio. c. 1490b. "Trattato di architettura civile e militare". Codex Magliabecchiano II. 1. 141. Florence: Biblioteca Nazionale.

Monge, Gaspard. 1798. Géométrie descriptive, leçons données aux Écoles normales, l'an 3 de la République. Paris: Baudouin.

Peruzzi, Baldassare. c. 1520. Ms. Accademia delle Belle Arti, Florence. Coll. E. 2.1.28. 
Parronchi, Alessandro. 1982. Introduzione. In Baldassare Peruzzi, Trattato di architettura militare. 5-54. Firenze: Gonelli.

Poudra, Nöel-Germinal. 1864. Histoire de la perspective ancienne et moderne. Paris: Corréard.

Rabasa, Enrique. 1999. Auguste Choisy. Vida y obra. In El arte de construir en Roma, ed. Auguste Choisy, xi-xxvii Madrid: Instituto Juan de Herrera.

Reichlin, Bruno. 1979. L'assonometria come progetto. Lotus, 22.

Reti, Ladislao. 1963. Francesco di Giorgio Martini's Treatise on Engineering and Its Plagiarists. Technology and Culture 4, 287-298 (Summer 1963).

Rojas y Sarmiento, Juan. 1550. Commentarium in astrolabium, quod planishperium vocant, libri sex. Paris.

Sakarovitch, Joël. 1997. Epures d'architecture. Basel-Boston-Berlin: Birkhäuser.

von Schlosser, Julius. 1924. Die Kunstliteratur. Ein Handbuch zur Quellenkunde der neueren Kunstgeschichte. Wien: Anton Schroll.

Scolari, Massimo. 1984. Elementi per una storia dell'assonometria. Casabella, 500, 42-49 (March 1984). Scolari, Massimo. 2005. Il disegno obliquo. Marsilio: Una storia dell'antiprospettiva. Venezia.

Serlio, Sebastiano. 1545. Il primo [-secondo] libro di architettura ... Paris: Iehan Barbe.

Vignola, Iacopo Barozzi, and Egnatio Danti. 1583. Le due regole della prospettiva prattica. Roma: Francesco Zanetti.

Villard de Honnecourt. c. 1225. Carnet, MS Fr 19093. Paris. Bibliothèque National de France.

Vredeman de Vries, Jan. 1604-1605. Perspective. Leiden-Den Haag.

Zanchi, Giovan Battista de. 1554. Del modo de fortificare la città. Venezia.

Miguel Ángel Alonso-Rodriguez is an architect and surveying engineer. He holds a Ph.D. in architecture; his dissertation focuses on the history of axonometry. He is Professor of descriptive geometry at the School of Architecture of the Polytechnical University of Madrid. He has also lectured in graduate courses on the history of axonometry and surveying at Madrid, the Universidad Nacional Autónoma de Guadalajara and the Ecole Politechnique d'Architecture et Urbanisme in Algiers. He has carried on surveys of historical buildings and archaeological sites in Spain, Pompei and the United Arab Emirates, both as the result of research grants, or as a commissions from such key Spanish institutions as Patrimonio Nacional and the Real Academia de San Fernando.

José Calvo-López is an architect. His Ph.D. dissertation was awarded the Extraordinary Doctoral Prize of the Polytechnic University of Madrid in 2001. He teaches graphical geometry, construction history and other subjects at the School of Architecture and Building Engineering of the Polytechnic University of Cartagena, where he is now director of the Master program in Architectural Heritage and the Doctoral program in Architecture. He has presented his research in seminars held at the Max-Planck Institute for the History of Science in Berlin, the Centre Alexandré Koyré (CNRS) in Paris, the Centro Alfredo Harp Helú in Oaxaca, international conferences and peer-reviewed journals. 